\title{
Left atrium compression due to oesophageal dilation can induce acute heart failure
}

\author{
Keisuke Nakabayashi, Tetsuo Hirata, Toshiaki Oka
}

Department of Cardiology, Seirei Hamamatsu General Hospital, Hamamatsu, Shizuoka, Japan

\section{Correspondence to} Dr Keisuke Nakabayashi, keisuke2018@gmail.com

Accepted 12 February 2015

\section{DESCRIPTION}

An 85-year-old woman reported sudden onset dyspnoea and subsequent vomiting after eating a large meal. She had normal blood pressure (124/ $60 \mathrm{~mm} \mathrm{Hg}$ ) but was tachypnoeic $(28 / \mathrm{min})$. Coarse crackles were heard in all the lung fields, and chest radiography showed congestion. ECG showed a non-specific ST-T change, and the brain natriuretic peptide level was $35.2 \mathrm{pg} / \mathrm{mL}$. Transthoracic echocardiography demonstrated extrinsic left atrial (LA) compression (figure 1), and the tricuspid regurgitation pressure gradient was $42 \mathrm{~mm} \mathrm{Hg}$. Subsequently, contrast-enhanced CT revealed oesophageal dilation compressing the LA (figure 2).

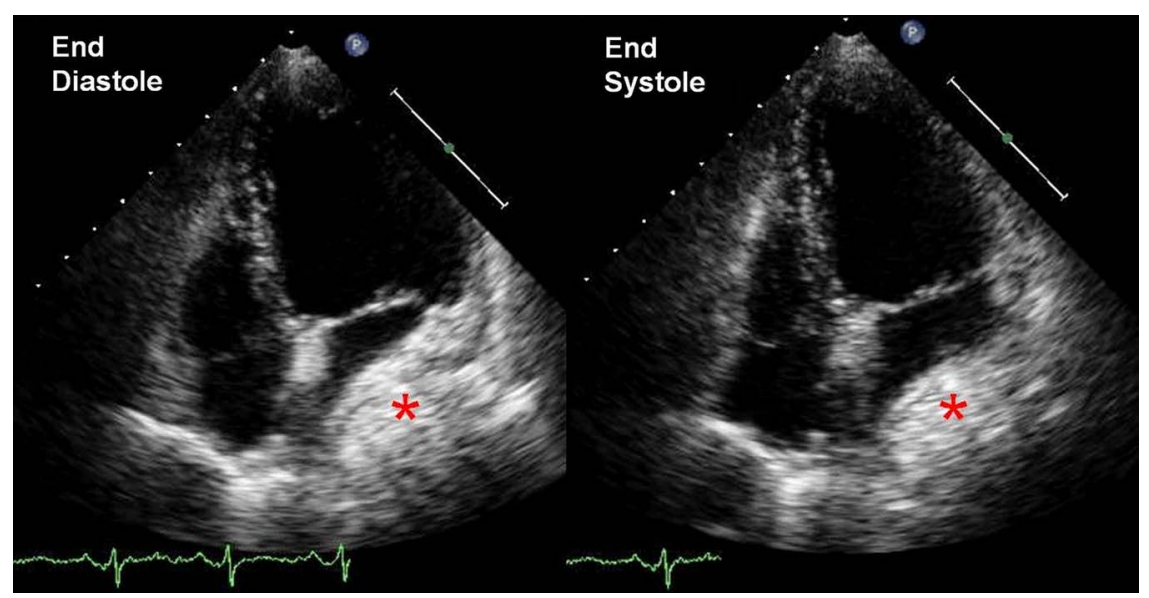

Figure 1 Transthoracic echocardiography. The asterisk indicates the left atrial mimicking mass, which is compressed by a large oesophageal dilation.

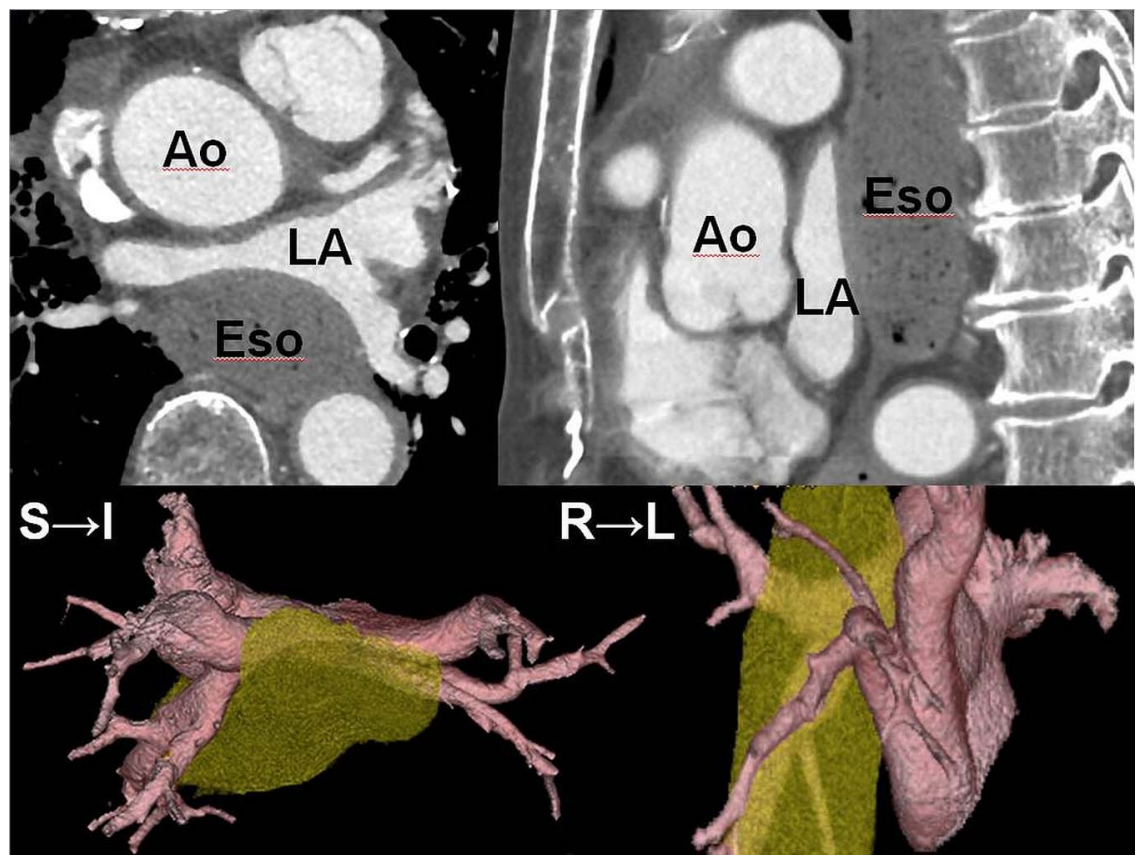

Figure 2 A contrast-enhanced CT scan. The upper columns in the axial and sagittal view on two-dimensional imaging demonstrating the geometry of the $L A$ and peri-organs. The lower columns on three-dimensional imaging showing the LA, which is compressed by the dilated esophagus. Ao, aorta; LA, left atrium; Eso, esophagus; pink cavity, left atrium; yellow trunk, esophagus. 


\section{Learning points}

Large oesophageal dilation can compress the left atrium and cause acute heart failure.

- Clinicians should pay attention to the anatomy of the pericardial organs when an unfamiliar mass-effect is located in the heart.

- Contrast CT is a very useful tool for understanding the anatomy of the heart and the surrounding organs.

On day 2, transoesophageal echocardiography did not reveal an accelerated flow while the patient had a full stomach. On an empty stomach, the right heart catheter revealed a mean pulmonary artery pressure, mean pulmonary capillary wedge pressure and heart rate of $10 \mathrm{~mm} \mathrm{Hg}, 8 \mathrm{~mm} \mathrm{Hg}$ and $80 \mathrm{bpm}$, respectively, which increased to $16 \mathrm{~mm} \mathrm{Hg}, 11 \mathrm{~mm} \mathrm{Hg}$ and $110 \mathrm{bpm}$, respectively, after eating. Upper gastrointestinal tract endoscopy showed no mechanical stenosis. Additional laboratory data ruled out connective tissue disease. Ultimately, we diagnosed the patient as idiopathic oesophageal dilation causing impingement on the LA.
The patient underwent conservative therapy (ie, eating frequent small meals, avoiding late meals, avoiding lying in a supine position immediately after eating, and sleeping in the semi-Fowler's position). ${ }^{1}$ The patient's symptoms gradually eased without intervention and on recent review she has been symptom free for 3 months.

Oesophageal hiatal hernia and achalasia can mimic an LA mass. $^{2}{ }^{3}$ However, this is the first case of oesophageal dilation that mimicked an LA mass and induced acute heart failure.

Contributors KN mainly treated the patient and wrote the manuscript, and TH and TO supervised it.

Competing interests None.

Patient consent Obtained.

Provenance and peer review Not commissioned; externally peer reviewed.

\section{REFERENCES}

1 Siu CW, Jim MH, Ho HH, et al. Recurrent acute heart failure caused by sliding hiatus hernia. Postgrad Med J 2005;81:268-9.

2 Chan J, Manning WJ, Appelbaum E, et al. Large hiatal hernia mimicking left atrial mass, a multimodality diagnosis. J Am Coll Cardiol 2009;54:569.

3 Yilmaz $\mathrm{MB}$, Arat N, Biyikoglu SF, et al. Extrinsic left atrial compression in a patient with achalasia. Int J Cardiol 2002;85:301-3.

Copyright 2015 BMJ Publishing Group. All rights reserved. For permission to reuse any of this content visit

http://group.bmj.com/group/rights-licensing/permissions.

BMJ Case Report Fellows may re-use this article for personal use and teaching without any further permission.

Become a Fellow of BMJ Case Reports today and you can:

- Submit as many cases as you like

- Enjoy fast sympathetic peer review and rapid publication of accepted articles

- Access all the published articles

- Re-use any of the published material for personal use and teaching without further permission

For information on Institutional Fellowships contact consortiasales@bmjgroup.com

Visit casereports.bmj.com for more articles like this and to become a Fellow 